\title{
Enzyme Inhibitor Screening by Electrospray Mass Spectrometry with Immobilized Enzyme on Magnetic Silica Microspheres
}

\author{
Fengli Hu, Huiying Zhang, Huaqing Lin, Chunhui Deng, and \\ Xiangmin Zhang \\ Department of Chemistry, Fudan University, Shanghai 200433, China
}

In this study, a novel technique for screening inhibitors by electrospray mass spectrometry (ESI-MS) with immobilized enzyme on magnetic microspheres has been demonstrated. First, the model enzyme acetylcholinesterase (AChE) is immobilized onto the 3-glycidoxypropyltrimethoxysilane (GLYMO)-modified magnetic silica microspheres. AChE activity was monitored by biochemical assay that is based on mixing of AChE immobilized microspheres and model substrate acetylcholine, separating and detecting the product through ESI-MS. Stability of the enzyme-immobilized microspheres was investigated. No apparent loss of enzyme activity was observed after fivefold reuse of AChE-immobilized microspheres. The enzymeimmobilized bioassay was used to effectively identify AChE inhibitors among two standard samples, huperzine A and huperzine B, and their source herbal Huperzia serrata, all of which were spiked into the substrate. The inhibition was determined by measuring a decrease of product formation using ESI-MS. (J Am Soc Mass Spectrom 2008, 19, 865-873) (c) 2008 American Society for Mass Spectrometry

$\mathrm{T}$ The enzyme acetylcholinesterase (AChE) plays a pivotal role in the nervous system. The principal function of this enzyme is the termination of nerve impulse transmission at the cholinergic synapses by rapid hydrolysis of the active neurotransmitter acetylcholine (ACh) into the inactive compounds choline and acetic acid. Low levels of ACh in the synaptic cleft are associated with Alzheimer's disease (AD), the most frequent disease affecting elderly people. Inhibition of AChE activity serves as a strategy for the treatment of AD [1-3]. Several synthetic drugs, such as galanthamine, have been approved for treatment of $\mathrm{AD}$ in the United States and some European countries [4-6]. They act as acetylcholinesterase inhibitors (AChEIs) and therefore increase the amount of free $\mathrm{ACh}$, which results in neuron transmission improvement [7]. Unfortunately, the available treatments are not satisfactory (undesirable side effects, low efficiency), and there is still a need for original drug development.

Techniques focusing on the enzyme model are well implemented in current pharmaceutical studies. Recently, some AChE assays based on colorimetrics have been described $[8,9]$. The biochemical assay was due to the AChE-catalyzed hydrolysis of the synthetic substrate acetylthiocholine into thiocholine. To obtain colorimetric readout, the product thicholine is allowed to react with an additional reagent to form a yellow-

Address reprint requests to C. Deng or X. Zhang, Department of Chemistry, Fudan University, Shanghai 200433, China. or E-mail: chdeng@ fudan.edu.cnxmzhang@fudan.edu.cn colored product that is detected by UV-Vis. Besides the additional reagent, the drawback of this assay is that compounds present in plant extracts are known to interface with the second reaction, thereby yielding false positives.

Immobilization of enzymes on various beads and surface materials has been widely used because they provide many advantages over free enzymes including: (1) reduced autolysis products and sample contamination [10, 11]; (2) label-free environment [12]; (3) rapid throughput [13]; (4) the possibility to recycle the studied enzymes or continuous reuse of the enzymes [14, 15]; (5) easy separation of the product from reaction media [16-18]; and (6) a multiplexed approach for the investigation of enzymes, allowing the coupling of different analytical techniques, such as mass spectrometry [19]. For example, a variety of methods have been reported for trypsin immobilization on various supports, such as polymer particles [20], glass [21, 22], membrane [23], gel beads [24], sol-gel supports [25], porous silicon matrix [26-28], porous monolithic materials [29-31], and paramagnetic microparticles [32]. In our group, trypsin has been immobilized on magnetic microspheres through covalent binding [33-35]. It has been demonstrated that good stability and reproducibility were obtained while the immobilized enzyme can be reused at several times. Magnetic microspheres draw great attention due to their ease of isolation from the reaction mixture with the assistance of a magnetic field.

Mass spectrometry techniques have been widely reported for detecting the enzymatic digestion of pro- 
tein. Early in 1998, Peter Hejrup and colleagues demonstrated that the immobilized enzymes can substitute for regular enzymes in protein chemistry protocols with the help of matrix-assisted laser desorption/ionization mass spectrometry (MALDI-MS) [22]. Mass spectrometry is the standard for trace-level determination of compounds in complex mixtures [36-38]. Attempts to carry out the quantitative validation of the measurement of biological compounds were also reported [39, 40]. In the pharmaceutical industry, this has led to the routine use of these techniques to monitor pharmacokinetics and bioavailability of drug compounds in biological matrices. Mass spectrometry has also been applied to measure the conversion of substrates to products for enzyme assays [41]. Cancilla et al. hyphenated immobilized enzyme technologies and electrospray mass spectrometry (ESI-MS) to screen enzyme inhibitor candidates from complex mixtures [42]. Potential inhibitors are quickly identified by comparison of the spectra change in ion intensity before and after incubation with the immobilized enzyme.

Here, we introduce a very simple and effective method of immobilization of enzyme directly onto 3-glycidoxypropyltrimethoxysilane (GLYMO)-modified magnetic silica microspheres. The epoxy group of GLYMO can easily capture the enzyme via amidefunctionalized groups. The performance of the immobilized enzyme was tested by ESI-MS after incubation with substrate acetylcholine. To confirm its use in a pharmaceutical study, we spiked the substrate with two possible enzyme inhibitors and incubated the mixture with immobilized AChE. In the absence of inhibitor, the substrate was converted to acetic acid and product (choline), whereas in the presence of an inhibitor, this reaction was quenched. The reactants were subsequently analyzed by ESI-MS. These two possible candidates, the lycopodium unsaturated sesquiterpene alkaloids huperzine A (Hup A) and huperzine B (Hup B) [43, 44], have demonstrated specific and reversible inhibition of AChE. Their potencies, especially for Hup A, are similar or superior to those of the already clinically approved AChEIs [44, 45]. According to clinical studies, Hup A satisfies all criteria for a potential new drug in the symptomatic treatment of AD. It has a long duration of action, a high bioavailability after oral administration, and has minimal side effects. Furthermore, such inhibitor screening was tested on a traditional Chinese herbal, Huperzia serrata, a source of Hup A and Hup B, to demonstrate the feasibility of application on a complicated system.

\section{Experimental}

\section{Chemical and Materials}

3-Glycidoxypropyltrimethoxysilane (GLYMO), acetylcholinesterase $(\mathrm{AChE})$, and acetylcholine $(\mathrm{ACh})$ were purchased from Sigma Chemicals (St. Louis, MO, USA). Chlormequat was from Alfa Aesar (Ward Hill, MA,
USA). Distilled water was purified by Milli-Q system (Milford, MA, USA). Huperzine A and huperzine B were purchased from the Institute for the Control of Pharmaceutical and Biological Products of China (Beijing, China). Huperzia serrata was purchased from a local Chinese medicine store in Shanghai province of China. Other reagents were analytical grade and purchased from Shanghai Chemical Reagent Co. (Shanghai, China). Ammonium bicarbonate (10 mM, pH 7.8) was used as buffer.

Preparation and Characterization of GLYMO-Modified Magnetic Silica Microspheres. Magnetic silica (MS) microspheres with core-shell structure were first synthesized in our laboratory. The magnetic microspheres were synthesized through solvothermal reaction, described as follows: $2.70 \mathrm{~g}$ of $\mathrm{FeCl}_{3} \cdot 6 \mathrm{H}_{2} \mathrm{O}$ was first dissolved in $100 \mathrm{~mL}$ of ethylene glycol under magnetic stirring. A yellow clear solution was obtained after stirring for $0.5 \mathrm{~h}$. Then $7.20 \mathrm{~g}$ of NaAc (sodium acetate) was added to this solution. After being stirred for another $0.5 \mathrm{~h}$, the resultant solution was transferred into a Teflon-lined stainless steel autoclave with capacity of $200 \mathrm{~mL}$. The autoclave was sealed and heated at $200{ }^{\circ} \mathrm{C}$ for $8 \mathrm{~h}$ and cooled to room temperature. The black magnetic microspheres were collected by use of a magnet, followed by washing six times with recycle of ethanol and deioned water, after which the product was dried in vacuum at $60{ }^{\circ} \mathrm{C}$ for $12 \mathrm{~h}$.

To obtain core-shell MS microspheres with narrow size distribution and uniform thickness of silica via the sol-gel approach, magnetic microspheres $(0.01 \mathrm{~g})$ were first treated in $\mathrm{HCl}$ aqueous solution $(5.0 \mathrm{~mL}, 2 \mathrm{M})$ under ultrasonic vibration for $5 \mathrm{~min}$. Then, the microspheres were thoroughly washed with deionized water and redispersed in a mixture of ethanol $(70.0 \mathrm{~g})$, deioned water $(20.0 \mathrm{~g})$, and concentrated ammonia aqueous solution $(1.0 \mathrm{~g}, 28 \mathrm{wt} \%)$ with the help of ultrasonication, and a stable dispersion was obtained. Subsequently, tetraethyl orthosilicate $(0.05 \mathrm{~g})$ was added to the above dispersion under mechanical stirring and the reaction was allowed to proceed for $12 \mathrm{~h}$. Finally, by use of a magnet, the product was separated and washed with ethanol and water, and then vacuum dried at $60{ }^{\circ} \mathrm{C}$ for $24 \mathrm{~h}$.

In the final step, $0.05 \mathrm{~g}$ core-shell MS microspheres were dispensed in toluene with $1.5 \mathrm{~g}$ GLYMO added. The mixture was stirred at room temperature for $1 \mathrm{~h}$. Finally, the mixture was heated to $65^{\circ} \mathrm{C}$ for $6 \mathrm{~h}$.

Immobilization of AChE onto MS Microspheres. GLYMOmodified MS microspheres ( $3 \mathrm{mg}$ ) were transferred to a $0.6 \mathrm{~mL}$ Eppendorf (EP) tube and dispersed in $200 \mu \mathrm{L} 0.5$ $\mathrm{mg} / \mathrm{mL}$ AChE solution $\left(10 \mathrm{mM} \mathrm{NH} \mathrm{HCO}_{3}\right.$ as buffer, $\mathrm{pH}$ 7.8). The mixture was ultrasonicated for $1 \mathrm{~min}$ to form a homogeneous suspension. Then the suspension was rotated at $37^{\circ} \mathrm{C}$ for $2 \mathrm{~h}$. After that, the supernatant solution was removed with the help of a magnet. The retained magnetic microspheres were washed three 


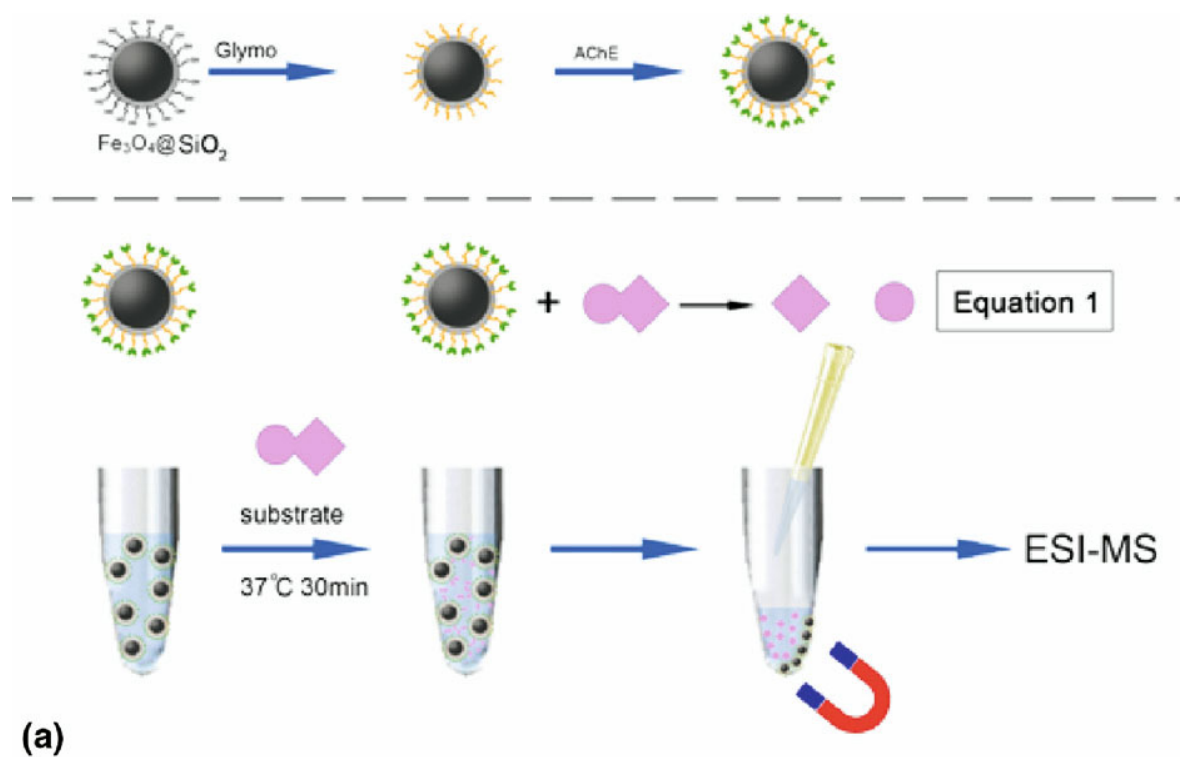

(a)

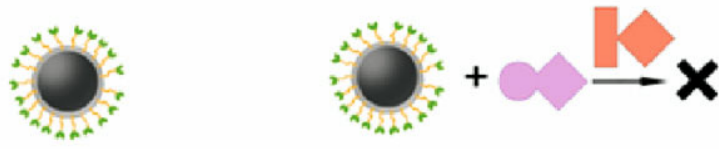

Equation 2

(b)
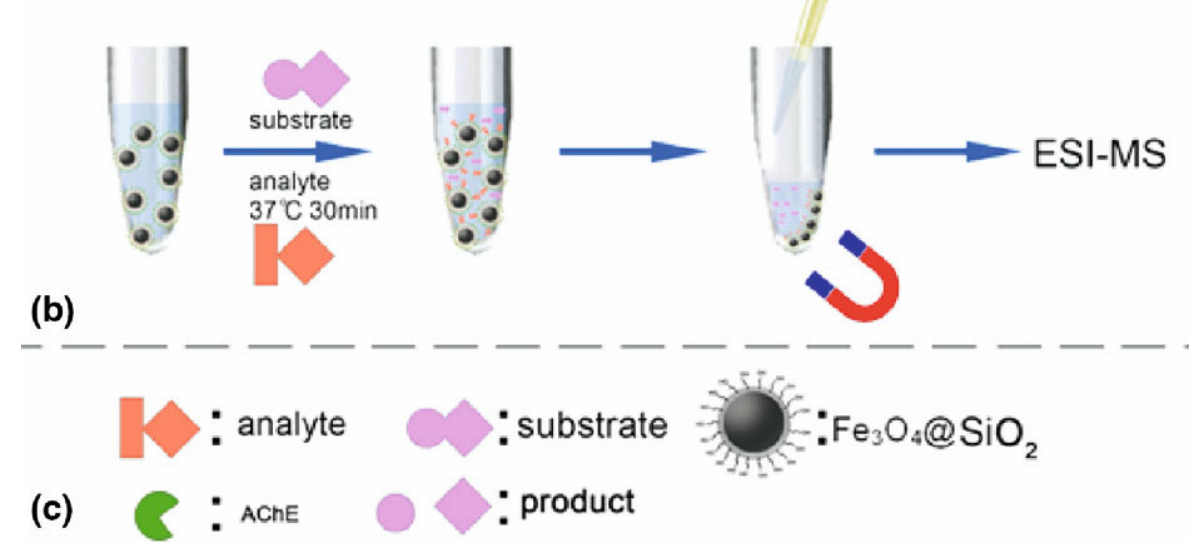

Figure 1. (a) Illustration of synthesis of AChE-immobilized MS microspheres. (b) Schematic diagram of biochemical assay without inhibitors by using AChE-immobilized MS microspheres. (c) Schematic diagram of biochemical assay with inhibitors by using AChE-immobilized MS microspheres.

times with buffer, redispersed in $600 \mu \mathrm{L}$ buffer, and stored at $4{ }^{\circ} \mathrm{C}$ before assay. The simple immobilization is illustrated in Figure 1a.

The UV absorption value of the supernatant solution was measured at $\lambda=280 \mathrm{~nm}$ and compared to the UV absorption value of the AChE solution before immobilization to calculate the amount of AChE immobilized on the MS microspheres.

\section{Acetylcholinesterase Assay}

Briefly, the reaction mixture of AChE-immobilized micropheres $(20 \mu \mathrm{L})$ and substrate $(10 \mu \mathrm{L} 200 \mathrm{mM}$ acetylcholine), in the presence or absence of drug (32 mM Hup A, $30 \mathrm{mM}$ Hup B, and $7.7 \mathrm{mg} / \mathrm{mL} \mathrm{H}$. serrata), prepared in buffer to a final volume of $130 \mu \mathrm{L}$, was incubated for $30 \mathrm{~min}$ at $37^{\circ} \mathrm{C}$. Then a magnet was used to gather and isolate the microspheres. The supernatant was removed to a new EP tube and $10 \mu \mathrm{L} 200 \mathrm{mM}$ chlormequat was added into the solution. Finally, an aliquot of $5 \mu \mathrm{L}$ above supernatant was analyzed by ESI-MS. The flowchart of the preceding process is illustrated in Figure 1b, c.

\section{Mass Spectrometry}

The ESI-MS was LC-IT-TOF MS-2010A from Shimadzu (Kyoto, Japan). The mass system consisted of an electrospray ionization (ESI) interface. The ionization parameters were as follows: positive-ion mode; capillary voltage $4000 \mathrm{~V}$, end plate voltage $500 \mathrm{~V}$; nebulizing gas of nitrogen at 35.0 p.s.i.; and drying gas of $10.0 \mathrm{~L} / \mathrm{min}$ 
nitrogen at $365^{\circ} \mathrm{C}$. The mass analyzer scanned from 100 to $1000 \mathrm{u}$. The MS spectra were recorded in auto-MS mode. The fragmentation amplitude was set to $2.0 \mathrm{~V}$.

\section{Extraction of Huperzia serrata}

About $10 \mathrm{~g}$ of $H$. serrata was crushed with a grinder and heated with $100 \mathrm{~mL}$ chloroform for $2 \mathrm{~h}$. The chloroform was removed by using the rotary vacuum evaporator. The residues obtained were dissolved in $0.01 \mathrm{M} \mathrm{HCl}$ and extracted twice with chloroform. The $\mathrm{pH}$ of the water solute was adjusted to 10 by adding $1 \mathrm{M} \mathrm{NaOH}$ to the mixture. Then the extract was extracted with chloroform twice again. The chloroform-solute was collected and lyophilized before use.

\section{Immobilized Enzyme Recycling}

To allow repeating screening, the enzymes were recycled. After enzymatic reaction, the supernatant was removed for analysis via MS. Three $200-\mu \mathrm{L}$ washes of incubation buffer were added to the residual micropheres followed by light shaking and removal of the supernatant. The immobilized enzymes were then denatured to release the bound compounds. The denaturing wash was performed by adding two 200- $\mu \mathrm{L}$ aliquots of $\mathrm{MeOH}$ to the immobilized enzyme microspheres and heating at $65^{\circ} \mathrm{C}$ for $10 \mathrm{~min}$, followed by isolation and collection of the supernatant with use of the magnet. The $\mathrm{MeOH}$ washes were combined and vacuum centrifuged to dryness.

\section{Results and Discussion}

\section{Performance of Immobilized Acetylcholinesterase}

The magnetite microspheres synthesized via the solvothermal reaction had a mean diameter of about $300 \mathrm{~nm}$ (Figure S1a, supporting information, which can be found in the electronic version of this article) according to the transmission electron microscope (TEM) observation. After being coated with silica through the sol-gel approach, core-shell structured magnetic silica microspheres with single magnetite core and uniform silica shell ( $\sim 70 \mathrm{~nm}$ in thickness) were obtained (Fig. S1b, supporting information). The thick silica shell was formed uniformly, thus providing magnetic microspheres with a silica-like surface for further modification. GLYMO was chosen as the derivative reagent for magnetic silica microspheres. By comparison with other reactive "spacer" groups such as diol, aldehyde, and tresyl groups, the epoxy group shows better immobilization ratio and ability of the enzyme for structural recognition [46]. Fourier transfer infrared (FT-IR) spectroscopy characterization confirmed the successful modification of the magnetic silica microspheres by GLYMO molecules (Figure S2, supporting information). The immobilization ability of GLYMO-modified magnetic silica microspheres for AChE immobilization was determined by measuring the UV absorption value of the supernatant enzyme solution after the immobilization procedure. The amount of AChE immobilized on the magnetic microparticles was calculated to be about $50 \mu \mathrm{g} / \mathrm{mg}$.

Figure 1 shows the process of the AChE assay: AChE-coated MS microspheres were transferred to a 0.6 $\mathrm{mL}$ EP tube and dispersed in buffer solution. After being incubated with substrate ACh under $37^{\circ} \mathrm{C}$ for an appropriate time, the reactant can be quickly and easily separated while the magnetic silica microspheres were retained by magnet. Equation 1 (Figure $1 b$ ) shows what happened in the enzyme-substrate mixture. Finally, ESI-MS was applied to detect the release of product. Acetylcholinesterase (AChE) can rapidly hydrolyze acetylcholine (ACh, $m / z 146.1)$ into choline $(m / z$ 104.1) and acetic acid. Provided the substrate was hydrolyzed to be a product, two special ion peaks at $\mathrm{m} / \mathrm{z} 146.1$ and 104.1 can be found in the MS spectrum. Easy manipulation was set up since there was no particular requirement of separation technique.

Before investigating the performance of the immobilized enzyme, the conditions for incubation or digestion were compared and optimized. To achieve optimum compatibility between the biochemical assay and MS detection conditions, $10 \mathrm{mM} \mathrm{NH} \mathrm{HCO}_{3}$ was selected to be the incubation buffer. Then, three enzymatic hydrolyses with different digestion times-15, 30, and 60 min-were compared in terms of enzyme activity, which is the ratio of ion intensity of the substrate to an internal standard (chlormequat). After hydrolysis for 15 min, the enzyme activity was $15 \%$ lower than that of 30 and 60-min hydrolyses. Figure 2 shows their typical MS spectrum together with their comparison of enzyme activity. However, with 60-min hydrolysis, no apparent increase of activity was observed. Thus, 30 min should be the optimum incubation time for the enzymatic hydrolysis.

Furthermore, to test the performance of the immobilized enzyme, we compared the hydrolysis effect of the normal enzyme in solution. The assay with free enzyme was performed as follows: mixtures of $5 \mu \mathrm{g} \mathrm{AChE}$ and substrate were incubated for $30 \mathrm{~min}$ at $37^{\circ} \mathrm{C}$; then $20 \mu \mathrm{L}$ acetonitrile was added to terminate the reaction. Amounts of AChE and ACh were identical to those of the immobilized enzyme. Figure 3 shows the behavior of the immobilized enzyme and the free enzyme through comparison of the ratio of peak intensity of acetylcholine to chlormequat. Three replicate assays with each enzyme were performed. It seems that the immobilized enzyme exerts a greater effect than that of free enzyme. Since the MS microspheres have a large surface area, the high concentration of immobilized enzyme would be achieved at a certain volume. Thus, the substrate might be in contact with $\mathrm{AChE}$ for a longer time compared with that of the solute system [47]. Another advantage of the immobilized enzyme here is that there is no need of an organic solvent, which may result in possible interference on MS. 


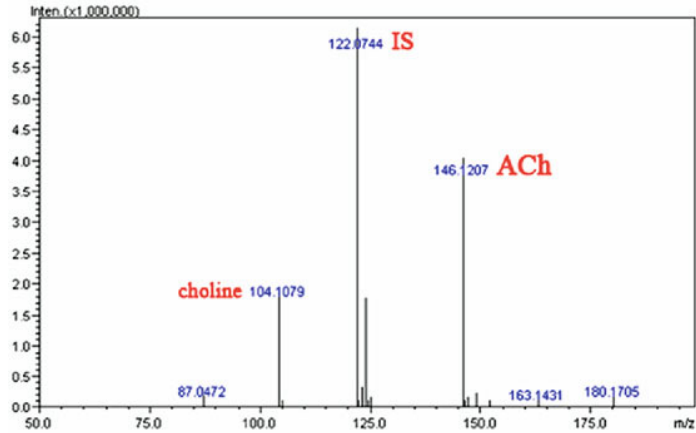

(a)

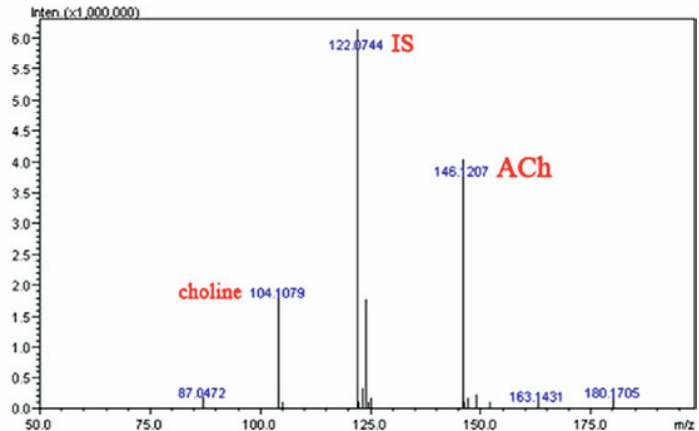

(b)
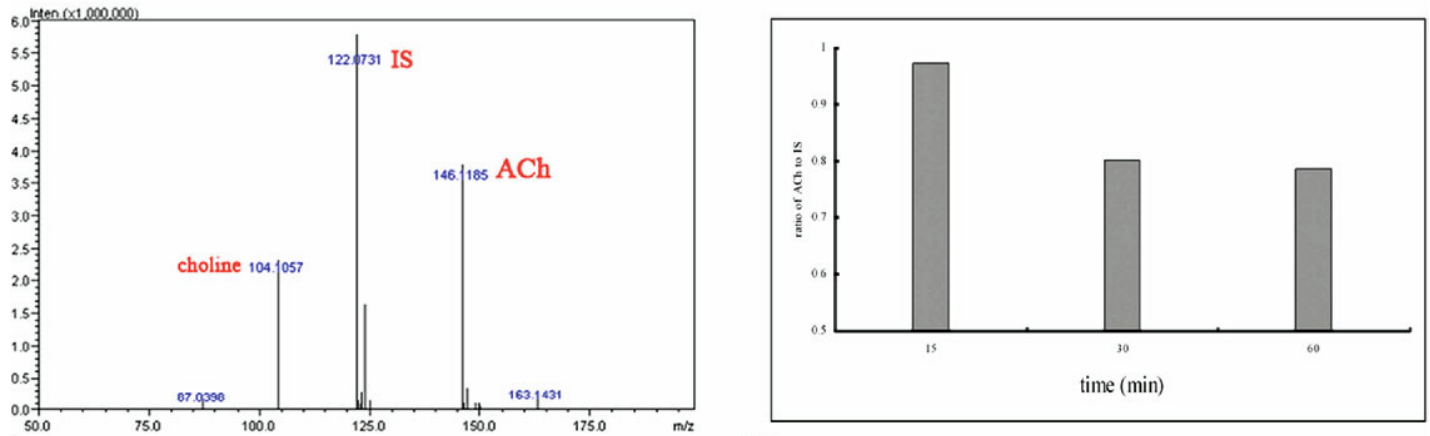

(c)

(d)

Figure 2. Mass spectrum of ACh hydrolyzed by immobilized AChE under different time: (a) 15 min (b) $30 \mathrm{~min}$, and (c) $60 \mathrm{~min}$. Buffer: $10 \mathrm{mM} \mathrm{NH}_{4} \mathrm{HCO}_{3}$. (d) Comparison of enzyme activity under above conditions.

\section{Semiquantitative Evaluation of the Enzyme \\ Activity}

Semiquantitative analysis of low-mass compounds by ESI-MS has been previously described in detail [39, 40]. Here, semiquantitative monitoring of immobilized enzyme activity through ESI-MS was demonstrated. As a structural analog, chlormequat was chosen as the internal standard for quantitative analysis of acetylcholine and choline. The relative standard deviation of five independent evaluations of $20 \mu \mathrm{M}$ acetylcholine (with the internal standard of $20 \mu \mathrm{M}$ ) was less than $10 \%$ (figures not shown).

Using the method of ESI-MS to detect the reaction of hydrolyzing acetylcholine to choline catalyzed by immobilized acetylcholinesterase in vitro was quantita-

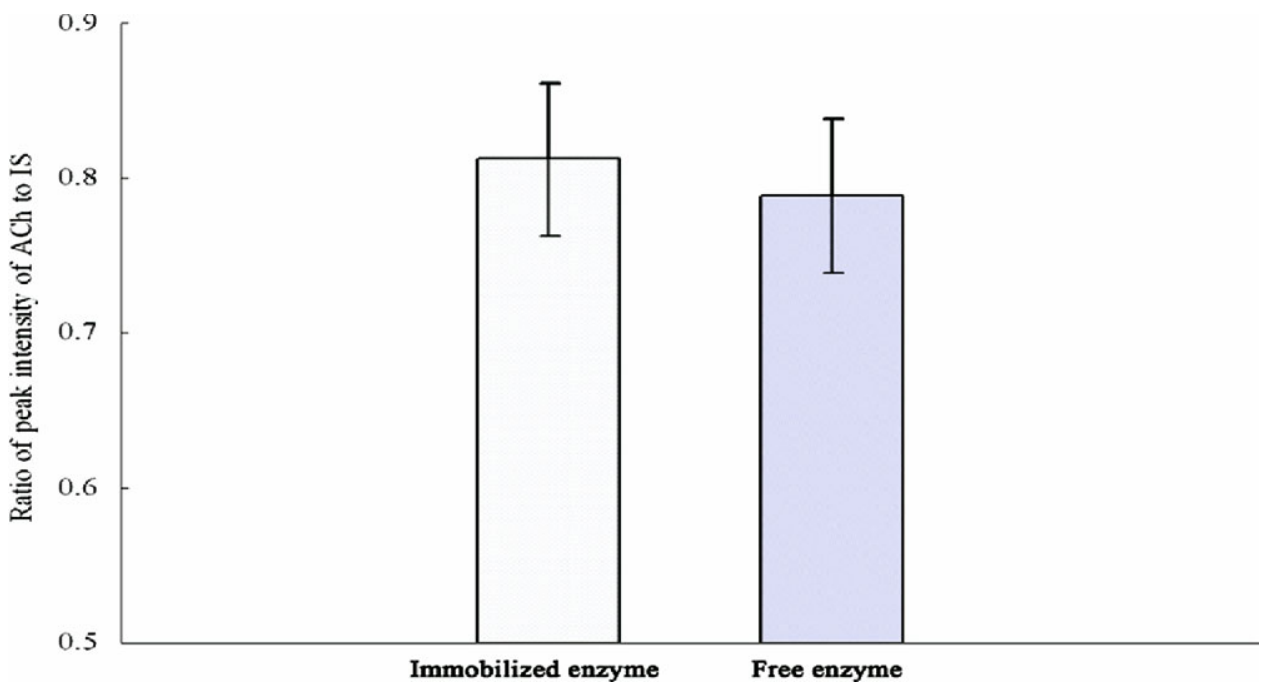

Figure 3. Comparison of enzyme activity through hydrolysis by immobilized AChE and free enzyme in solution. Buffer: $10 \mathrm{mM} \mathrm{NH}_{4} \mathrm{HCO}_{3}$. Incubation time: $30 \mathrm{~min}$. Every bar represents the ratio of ion intensity of substrate to internal standard. The error bar indicate standard deviations $(n=3)$. 


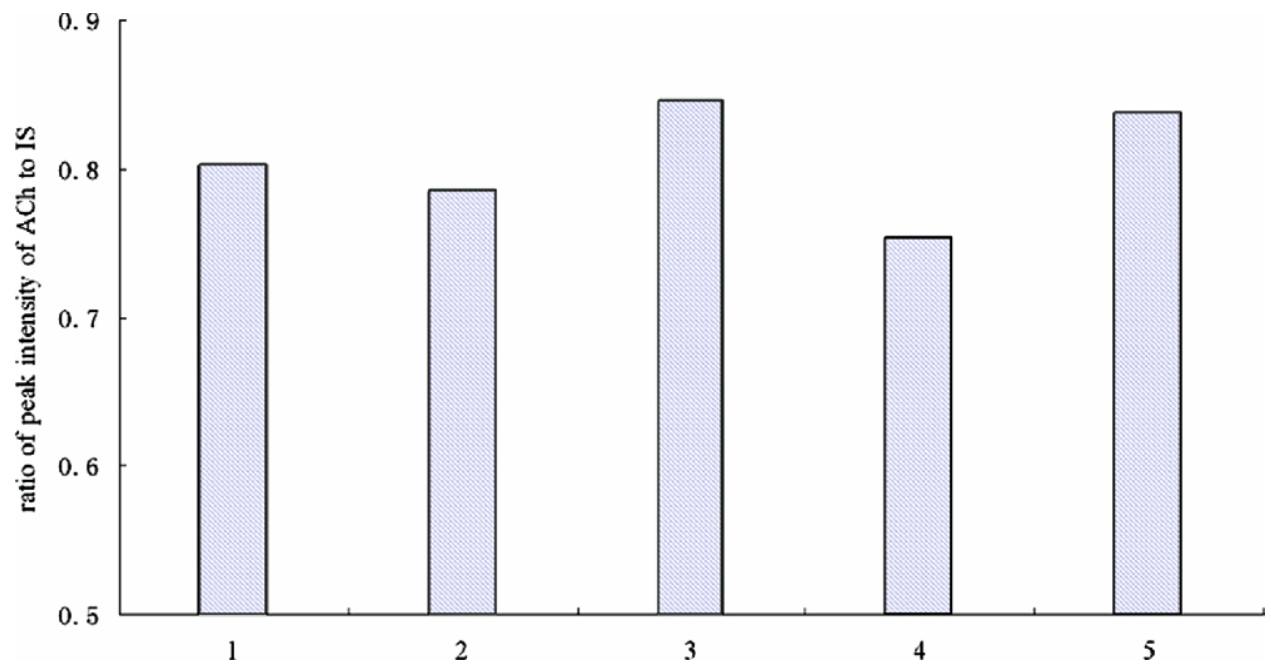

Figure 4. Comparison of enzyme activity from five AChE assays reacted with the reused immobilized enzyme microspheres. The activity was calculated by ratio of ion intensity of substrate to internal standard.

tively monitored. As shown in Figure 2, the hydrolyzing reaction is observed through the appearance of choline and reduction of acetylcholine. Under optimized condition, acetylcholine is hydrolyzed to choline within $30 \mathrm{~min}$. Activity of the immobilized enzyme was determined by the ratio of peak intensity of acetylcholine to chlormequat. Chlormequat was used not only as an internal standard for semiquantitative analysis but also as a standard to evaluate spectrum quality.

\section{Recycling and Reuse of Enzyme}

After enzymatic hydrolysis, the AChE-coated microspheres were quickly gathered and removed by use of a magnet. Then, three 200- $\mu \mathrm{L}$ washes of incubation buffer were added to the micropheres followed by light shaking and removal of the supernatant. The immobilized enzymes were then renewed and can once again be used to catalyze the enzymatic reaction.

The reproducibility of the immobilized enzyme was investigated through five consecutive assays for $\mathrm{ACh}$ with incubation for $30 \mathrm{~min}$ at $37^{\circ} \mathrm{C}$ using the same immobilized AChE. The results were then analyzed by ESI-MS. Figure 4 shows the enzyme activity of five successive enzymatic reactions catalyzed by the same group of enzyme-coated microspheres. The activity of immobilized enzyme, in terms of the ratio of ion intensity of substrate to internal standard, is evaluated in the form of a bar chart in Figure 4. The acetylcholinesterase immobilized onto GLYMO-modified MS microspheres remained active during the five hydrolysis reactions with little difference among the five spectra. Thus it should be inferred that the activity of immobilized enzyme is guaranteed even after five repeatable applications. It should be noted that, although only a small amount of enzyme had been immobilized onto the microspheres, its performance was sufficiently high to rapidly catalyze the reaction and maintain good repeat- ability. Recycling of enzyme can enhance a material's efficiency, thus decreasing the test cost.

When stored at $4{ }^{\circ} \mathrm{C}$, the stability of the AChEimmobilized MS microspheres seemed excellent. In detail, three groups of $\mathrm{AChE}$ were immobilized onto silica microspheres on the first day. The first group was used to hydrolyze the substrate on the first day. The second and third groups were applied to enzymatic hydrolysis on the third day and fifth day, respectively. The ratio of ion intensity of substrate to internal standard is shown in Figure 5. Since the ratio scarcely changes (RSD 3\%), it seems that the activity of immobilized acetylcholinesterase was not diminished when stored at $4{ }^{\circ} \mathrm{C}$. The ability of the enzyme to adhere to GLYMO-modified silica magnetic microspheres was so strong that the enzyme still catalyzed the reaction very effectively over a long period of storage (5 days).

Consequently, the immobilized enzyme model may reduce the cost of testing since the enzyme-coated microspheres can be recycled but still maintain good reproducibility and stability. The immobilized enzyme behaves more effectively than the enzyme in solution.

\section{Inhibitor Screening}

Hup A and Hup B have proved to be promising drugs in the treatment of AD. The key mechanism of their treatment is the inhibition effect on acetylcholinesterase. Here, we select them to serve as the standard drugs to develop an enzyme inhibitor screening model. The model process was shown earlier in Figure 1c: AChEimmobilized microspheres were well dispersed in the buffer; they were then incubated with substrate and analyte (Hup A or Hup B) at $37^{\circ} \mathrm{C}$ for 30 min; quickly isolated with use of a magnet; and finally the supernatant was detected by ESI-MS. Equation 2 (Figure 1c) shows what occurs in the enzyme-substrate-analyte mixture. If the analyte takes effect, the enzyme will be 


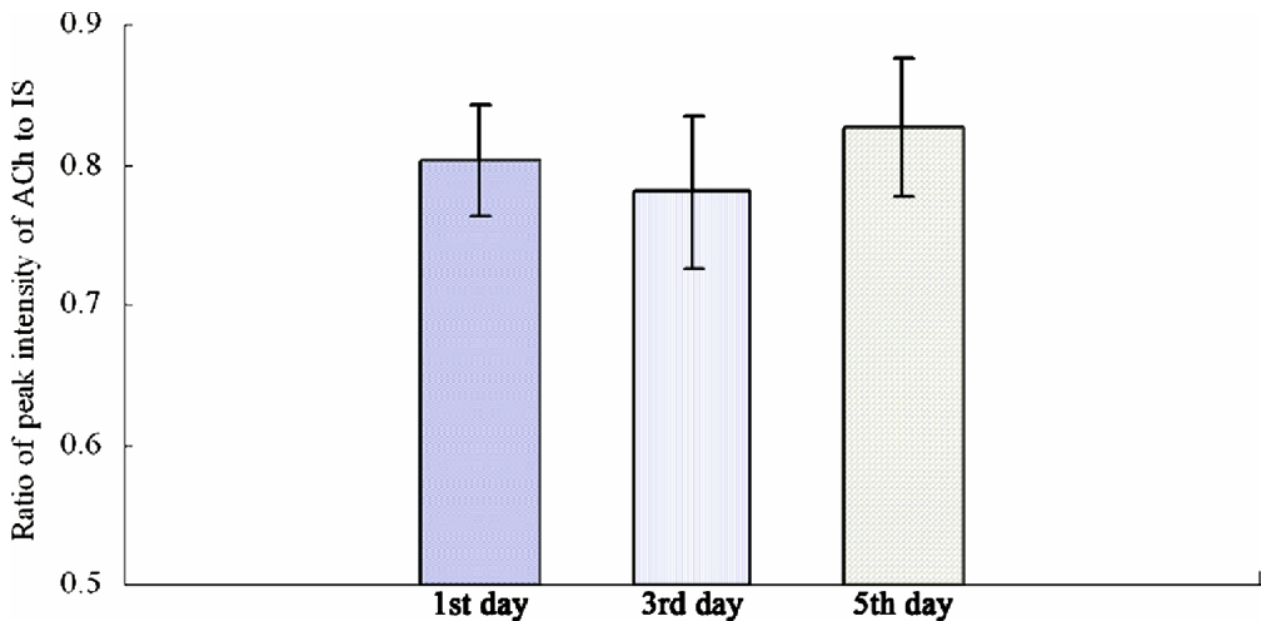

Figure 5. Comparison of enzyme activity from every two days' AChE assays reacted with the enzyme immobilized on the first day. Enzyme activity was evaluated as above. The error bar indicate standard deviations $(n=3)$.

blocked and the hydrolysis reaction will be quenched. The change expressed in the MS spectra is that the ion intensity of the peak at $m / z 104.1$ (product) will become weaker or disappear. The intensity varies with the drug's pharmaceutical effect. Figure $6 a, b$ shows the mass spectra of the assay with Hup A and Hup B. The product's peak vanishes in Figure $6 a, b$, suggesting that Hup A and Hup B were apparently strong inhibitors for AChE. This result is in agreement with that reported in other studies [30-32]. Peaks at $m / z 243.1$ and 257.1 imply the existence of Hup A (MS: 242) and Hup B (MS: 256).

By relating the assay for activity (Figure $1 \mathrm{~b}$, eq 1 ) and that for inhibition (Figure 1c, eq 2), we may illustrate a simple principle of how the inhibitors exert their influence on enzymatic hydrolysis. It can be explained by the key-lock theory. The enzyme is like a lock and the substrate is like a key, so structural characteristics of the

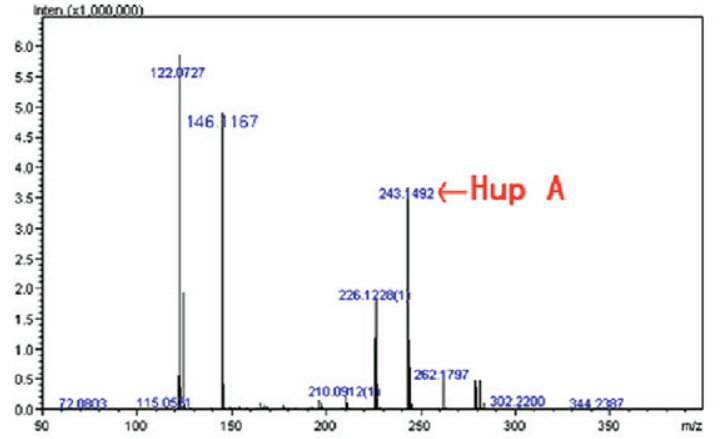

(a)

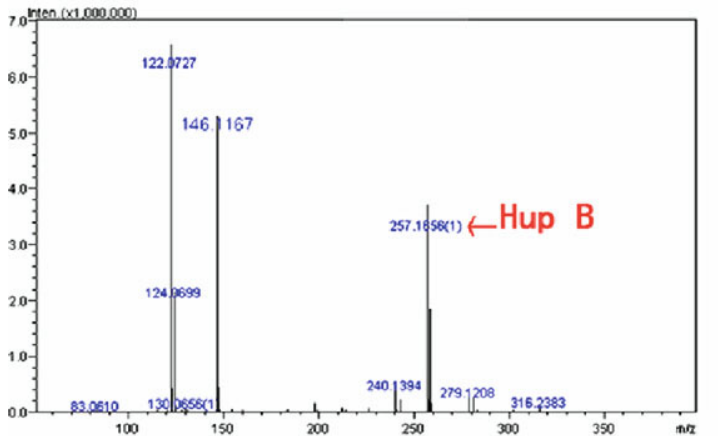

(b)

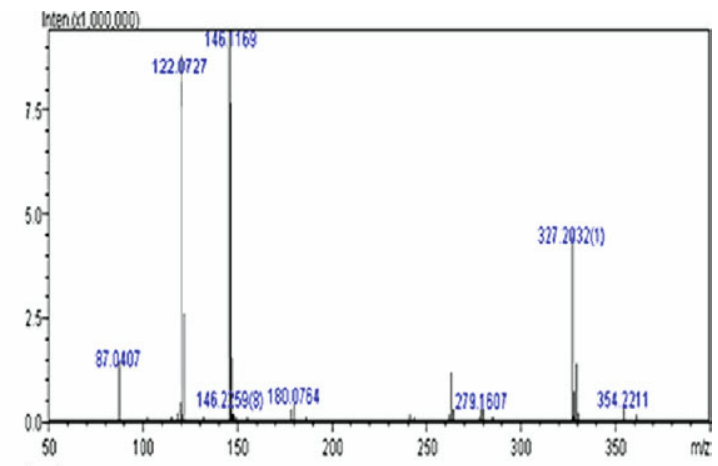

(c)

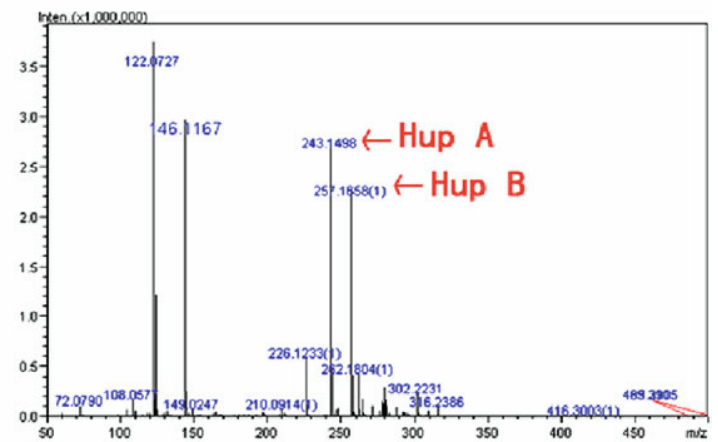

(d)

Figure 6. Typical MS spectra for screening inhibitors in (a) Hup A, (b) Hup B, and (c) Huperzia serrata. (d) Control, mixture of $H$. serrata and substrate. 
contact area of the two compounds relate to each other. For $\mathrm{AChE}$ and $\mathrm{ACh}$, the relationship is expressed as a negative-ion structure in enzyme and a positive-ion structure (quaternary ammonium ion) in substrate. As shown in Figure 1 (bottom), the enzyme is pictured as a sector loss of a quarter whose form is similar to the corner in the substrate. This mutual structure leads to their possible contact, thus forming an enzyme-substrate complex. Afterward, the hydrolysis reaction occurs since the choline disappears from the complex. Enzyme and inhibitors may also be characterized as a lock and key combination. Inhibitors also have a related corner. As a result, substrate and inhibitor will compete against each other to contact the enzyme. Such competition will somewhat reduce the probability of combining enzyme with substrate.

To investigate the effect of the aforementioned inhibitor screening model, it was performed on a complicated sample. The Chinese herbal Huperzia serrata, the source of Hup A and Hup B, should contain several bioactive compounds that inhibit the activity of AChE. An extract of the herbal was incubated with the immobilized enzyme and substrate. The result is demonstrated in the MS spectrum shown in Figure 6c. Figure $6 \mathrm{~d}$ shows the MS spectrum of the mixture with substrate and $H$. serrata. By comparing these two spectra, it can be concluded that the herbal inhibits acetylcholinesterase with the integrative effect of several compounds besides Hup A and Hup B since several peaks disappeared. There are other constituent parts of the herbal that are worthy of further investigation, especially for pharmaceutical study. Above all, the inhibitor screening model can be applied without limitation to a complicated system.

\section{Conclusions}

A novel method for screening the AChE inhibitor was established, based on ESI-MS and AChE immobilized onto magnetic silica microspheres. Due to the fast and efficient removal of the enzyme-coated magnetic microspheres with the use of a magnet, the previous enzyme allows one to analyze the reactant without any kind of separation and purification. Compared to an in-solution enzyme, the immobilized enzyme can be recycled and reused up to five times based on its good reproducibility and stability. This leads to the possibility of reduced cost. Some of the new features presenting here demonstrate that the immobilization enzyme onto magnetic microspheres is able to directly replace the common form of enzyme digestions and can be applied to pharmaceutical study with no apparent limitations.

\section{Acknowledgments}

The work was supported by the National Basic Research Priorities Program (Project: 2007CB914100/3), The National High Technology Research and Development Program of China 863 Project (No. 2006AA02Z4C5), the National Key Natural Science Foundation of
China (Project: 20735005), and Shanghai Leading Academic Discipline Project (B109).

\section{References}

1. Bartus, R. T.; Dean, R. L.; Beer, B.; Lippa, A. S. The Cholinergic Hypothesis of Geriatric Memory Dysfunction. Science 1982, 217, $408-$ 417.

2. Perry, E. K. The Cholinergic Hypothesis-Ten Tears On. Br. Med. Bull. 1986, 42, 63-69.

3. Greenblatt, H. M.; Dvir, H.; Silman, I.; Sussman, J. L. Acetylcholinesterase-A Multifaceted Target for Structure-based Drug Design of Anticholinesterase Agents for the Treatment of Alzheimer's Disease. J. Mol. Neurosci. 2003, 20, 369-383.

4. Zangara, A. The Psychopharmacology of Huperzine A: An Alkaloid with Cognitive Enhancing and Neuroprotective Properties of Interest in the Treatment of Alzheimer's Disease. Pharmacol. Biochem. Behav. 2003, $75,675-686$.

5. Livingston, G.; Katona, C. How Useful Are Cholinesterase Inhibitors in the Treatment of Alzheimer's Disease? A Number Needed to Treat Analysis. Int. J. Geriatr. Psychiatry 2000, 15, 203-207.

6. Ogura, H.; Kosasa, T.; Araki, S. Pharmacological Properties of Donepezil Hydrochloride (Aricept), a Drug for Alzheimer's Disease. Nippon Yakurigaku Zassh. 2000, 115, 45-51.

7. Winkler, J.; Thal, L. J.; Gage, F. H.; Fisher, L. J. Cholinergic Strategies for Alzheimer's Disease. J. Mol. Med. 1998, 76, 555-567.

8. Ingkaninan, K.; De Best, C. M.; Van der Heijden, R.; Hofte, A. J.; Karabatak, B.; Irth, H.; Tjaden, U. R.; Verporte, R. High-performance Liquid Chromatography with On-line Coupled UV, Mass Spectrometric and Biochemical Detection for Identification of Acetylcholinesterase Inhibitors from Natural Products. J. Chromatogr. A 2000, 872, 61-63.

9. Rhee, I. K.; Appels, N.; Luijendijk, T.; Irth, H.; Verpoorte, R. Determining Acetylcholinesterase Inhibitory Activity in Plant Extracts Using a Fluorimetric Flow Assay. Phytochem. Anal. 2003, 14, 145-149.

10. Calleri, E.; Temporini, C.; Perani, E.; Palma, A. D.; Lubda, D.; Mellerio, G.; Sala, A.; Galliano, M.; Caccialanza, G.; Massolini, G. Trypsin-based Monolithic Bioreactor Coupled On-line with LC/MS/MS System for Protein Digestion and Variant Identification in Standard Solutions and Serum Samples. J. Proteome Res. 2005, 4, 481-490.

11. Slentz, B. E.; Penner, N. A.; Regnier, F. E. Protein Proteolysis and the Multi-dimensional Electrochromatographic Separation of Histidinecontaining Peptide Fragments on a Chip. J. Chromatogr. A 2003, 984, 97-107.

12. Dal-Hee, M.; Jing, S.; Milan, M. Profiling Kinase Activities by Using a Peptide Chip and Mass Spectrometry. Angew. Chem. Int. Ed. 2004, 43, 5973-5977.

13. Babiak, P.; Reymond, J. A High-throughput, Low-volume Enzyme Assay on Solid Support. Anal. Chem. 2005, 77, 373-377.

14. Bautista, F. M.; Bravo, M. C.; Campelo, J. M.; Garcia, A.; Luna, D.; Marinas, J. M.; Remore, A. A. Covalent Immobilization of Acid Phosphatase on Amorphous AlPO4 Support. J. Mol. Catal. B Enzymatic 1999, 6, 473-481.

15. Yavuz, H.; Bayramoglu, G.; Kacar, Y.; Denizli, A.; Arıca, M. Y. Congo Red Attached Monosize Poly(HEMA-co-MMA) Microspheres for Use in Reversible Enzyme Immobilization. Biochem. Eng. J. 2002, 10, 1-8.

16. Sanjay, G.; Sugunan, S. Glucoamylase Immobilized on Montmorillonite: Synthesis, Characterization and Starch Hydrolysis Activity in a Fixed Bed Reactor. Catal. Commun. 2005, 6, 525

17. Torres, R.; Pessela, B. C. C.; Mateo, C.; Ortiz, C.; Fuentes, M.; Guisan, J. M.; Fernandez-Lafuente, R. Reversible Immobilization of Glucoamylase by Ionic Adsorption on Sepabeads Coated with Polyethyleneimine. Biotechnol. Prog. 2004, 20, 1297-1300.

18. Wang, F.; Guo, C.; Liu, H. Z.; Liu, C. Z. Reversible Immobilization of Glucoamylase by Metal Affinity Adsorption on Magnetic Chelator Particles. J. Mol. Catal. B Enzymatic 2007, 48, 1-7.

19. Giuseppe, G.; Marco, F.; Enrico, R.; Giuseppe, S.; Kwon, J. Y. A New Methodology for Monitoring the Activity of cdMMP-12 Anchored and Freeze-dried on Au (111). J. Am. Soc. Mass Spectrom. 2007, 18, 961-969.

20. Yamada, K.; Nakasone, T.; Nagano, R.; Hirata, M. J. Retention and Reusability of Trypsin Activity by Covalent Immobilization onto Grafted Polyethylene Plates. Appl. Polym. Sci. 2003, 89, 3574-3581.

21. Bonneil, E.; Mercier, M.; Waldron, K. C. Reproducibility of a Solid-phase Trypsin Microreactor for Peptide Mapping by Capillary Electrophoresis. Anal. Chim. Acta 2000, 404, 29-45.

22. Krogh, T. N.; Berg T.; Hejrup, P. Protein Analysis Using Enzymes Immobilized to Paramagnetic Beads. Anal. Biochem. 1999, 274, 153-162.

23. Cooper, J. W.; Chen, J. Z.; Li, Y.; Lee, C. S. Membrane-based Nanoscale Proteolytic Reactor Enabling Protein Digestion, Peptide Separation, and Protein Identification Using Mass Spectrometry. Anal. Chem. 2003, 75 , 1067-1074.

24. Jin, L. J.; Ferrance, J.; Sanders, J. C.; Landers, J. P. A Microchip-based Proteolytic Digestion System Driven by Electroosmotic Pumping. Lab Chip 2003, 3, 11-18.

25. Sakai-Kato, K.; Kato, M.; Toyo'oka, T. Creation of an On-chip Enzyme Reactor by Encapsulating Trypsin in Sol-Gel on a Plastic Microchip. Anal. Chem. 2003, 75, 388-393. 
26. Bengtsson, M.; Ekström, S.; Marko-Varga, G.; Laurell, T. Improved Performance in Silicon Enzyme Microreactors Obtained by Homogeneous Porous Silicon Carrier Matrix. Talanta 2002, 56, 341-353.

27. Slentz, B. E.; Penner, N. A.; Regnier, F. E. Protein Proteolysis and the Multi-dimensional Electrochromatographic Separation of Histidinecontaining Peptide Fragments on a Chip J. Chromatogr. A 2003, 984, 97-107.

28. Slysz, G. W.; Schriemer, D. C. On-column Digestion of Proteins in Aqueous-Organic Solvents. Rapid Commun. Mass Spectrom. 2003, 17, 1044-1050.

29. Xie, S. F.; Svec, F.; Fréchet, J. M. J. Design of Reactive Porous Polymer Supports for High Throughput Bioreactors: Poly(2-vinyl-4,4-dimethylazlactone-co-acrylamide-co-ethylene dimethacrylate) Monoliths. Biotechnol. Bioeng. 1999, 62, 30-35.

30. Calleri, E.; Temporini, C.; Perani, E.; Palma, A. D.; Lubda, D.; Mellerio, G.; Sala, A.; Galliano, M.; Caccialanza, G.; Massolini, G. Trypsin-based Monolithic Bioreactor Coupled On-line with LC/MS/MS System for Protein Digestion and Variant Identification in Standard Solutions and Serum Samples. J. Proteome Res. 2005, 4, 481-490.

31. Peterson, D. S.; Rohr, T.; Svec, F.; Fréchet, J. M. J. Dual-function Microanalytical Device by In Situ Photolithographic Grafting of Porous Polymer Monolith: Integrating Solid-phase Extraction and Enzymatic Digestion for Peptide Mass Mapping. Anal. Chem. 2003, 75, 5328-5335.

32. Tigrett, S.; Canton, M.; Elssner, T.; Kostrzewa, M.; Pacaud-Mercier, K. Rapid and Time-controlled Protein Digest by Trypsin-coated Magnetic Particles Prior to Mass Spectrometric Analysis. Mol. Cell. Proteomics 2006, 5, S226-S236.

33. Li, Y.; Yan, B.; Deng, C. H.; Yu, W. J.; Xu, X. Q.; Yang, P. Y.; Zhang, X. M. Efficient On-chip Proteolysis System Based on Functionalized Magnetic Silica Microspheres. Proteomics 2007, 7, 2330-2339.

34. Li, Y.; Xu, X.-Q.; Yan, B.; Deng, C.-H.; Yu, W.; Yang, P.-Y.; Zhang, X.-M. Microchip Reactor Packed with Metal-Ion Chelated Magnetic Silica Microspheres for Highly Efficient Proteolysis. J. Proteome Res. 2007, 6, 2367-2375

35. Li, Y.; Yan, B.; Deng, C.-H.; Tang, J.; Liu, J.-Y.; Zhang, X.-M. On-plate Digestion of Proteins Using Novel Trypsin-immobilized Magnetic Nanospheres for MALDI-TOF-MS Analysis. Proteomics 2007, 7, 36613671.
36. Hoke, S. H.; Morand, K. L.; Greis, K. D.; Baker, T. R.; Harbol, K. L.; Dobson, R. L. M. Int. I. Mass Spectrom. 2001, 212, 135-196.

37. Hopfgartner, G.; Bourgogne, E. Quantitative High-throughput Analysis of Drugs in Biological Matrices by Mass Spectrometry. Mass Spectrom. Rev. 2003, 22, 195-214.

38. Taylor, P. J. Matrix Effects: The Achilles Heel of Quantitative Highperformance Liquid Chromatography-Electrospray-Tandem Mass Spectrometry. Clin. Biochem. 2005, 38, 328-334

39. Piraud, M.; Vianey-Saban, C.; Bourdin, C.; Acquaviva-Bourdain, C. Boyer, S.; Elfakir, C.; Bouchu, D. A New Reversed-phase Liquid Chromatographic/Tandem Mass Spectrometric Method for Analysis of Underivatised Amino Acids: Evaluation for the Diagnosis and the Management of Inherited Disorders of Amino Acid Metabolism. Rapid Commun. Mass Spectrom. 2005, 19, 3287-3297.

40. Isaacson, C. W.; Usenko, C. Y.; Tanguay, R. L.; Field, J. A. Quantification of Fullerenes by LC/ESI-MS and Its Application to In Vivo Toxicity Assays. Anal. Chem. 2007, 79, 9091-9097.

41. Liesener, A.; Karst, U. Monitoring Enzymatic Conversions by Mass Spectrometry: A Critical Review. Anal. Bioanal. Chem. 2005, 382, 14511464

42. Cancilla, M. T.; Leavell, M. D.; Chow, J.; Leary, J. A. Mass Spectrometry and Immobilized Enzymes for the Screening of Inhibitor Libraries. Proc. Natl. Acad. Sci. U.S.A. 2000, 97, 12008-12013.

43. Liu, J.-S.; Zhu, Y.-L.; Yu, C.-M.; Zhou, Y.-Z.; Han, Y.-Y.; Wu, F.-W.; Qi, B.-F. The Structures of Huperzine-A and Huperzine-B, 2 New Alkaloids Exhibiting Marked Anticholinesterase Activity. Can. J. Chem. 1986, 64, 837-839.

44. Ma, X.-Q.; Gang, D. R. The Lycopodium Alkaloids. Nat. Prod. Rep. 2004, $21,752-772$

45. Bai, D.-L.; Tang X.-C.; He, X.-C. Huperzine A, a Potential Therapeutic Agent for Treatment of Alzheimer's Disease. Med. Chem. 2000, 7 , 355-374.

46. Shinkai, M.; Ito, A. Functional Magnetic Particles for Medical Application. Adv. Biochem. Eng. Biotechnol. 2004, 91, 191-220.

47. Sakai-Kato, K.; Kato, M.; Toyoka, T. On-line Trypsin-encapsulated Enzyme Reactor by the Sol-Gel Method Integrated into Capillary Electrophoresis. Anal. Chem. 2002, 74, 2943-2949. 